\title{
Identification of Immunodominant T Cell Epitopes of the Hepatitis B Virus Nucleocapsid Antigen
}

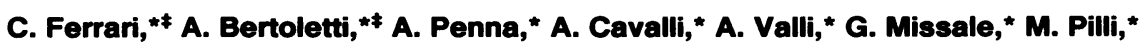 \\ P. Fowler," T. Giuberti,* F. V. Chisari, ${ }^{*}$ and F. Fiaccadori" \\ *Cattedra Malattie Infettive, Universita' di Parma, 43100 Parma, Italy; and 'Department of Experimental \\ and Molecular Medicine, Scripps Clinic and Research Foundation, La Jolla, California 92037
}

\begin{abstract}
Several lines of experimental evidence suggest that inclusion of core sequences in the hepatitis $B$ vaccine may represent a feasible strategy to increase the efficacy of the vaccination. In order to identify immunodominant core epitopes, peripheral blood $T$ cells purified from 23 patients with acute hepatitis $B$ and different HLA haplotypes were tested with a panel of 18 short synthetic peptides (15 to 20 amino acids [AA]) covering the entire core region. All patients except one showed a strong $T$ cell proliferative response to a single immunodominant 20 amino acid sequence located within the aminoterminal half of the core molecule. Two additional important sequences were also identified at the aminoterminal end and within the carboxyterminal half of the core molecule. These sequences were able to induce significant levels of $\mathrm{T}$ cell proliferation in 69 and $73 \%$ of the patients studied, respectively. $T$ cell response to these epitopes was HLA class II restricted. The observations that ( $a$ ) polyclonal $T$ cell lines produced by PBMC stimulation with native HBcAg were specifically reactive with the relevant peptides and that $(b)$ polyclonal $T$ cell lines produced with synthetic peptides could be restimulated with native $\mathrm{HBcAg}$, provide evidence that AA sequences contained within the synthetic peptides represent real products of the intracellular processing of the native core molecule. In conclusion, the identification of immunodominant $\mathbf{T}$ cell epitopes within the core molecule provides the molecular basis for the design of alternative and hopefully more immunogenic vaccines. (J. Clin. Invest. 1991. 88:214-222.) Key words: synthetic peptides • helper $T$ cells • polyclonal $\mathbf{T}$ cell lines $\bullet$ acute hepatitis $\bullet$ hepatitis $B$ vaccine
\end{abstract}

\section{Introduction}

The cell-mediated immune events involved in liver damage and viral clearance during hepatitis B virus $(\mathrm{HBV})^{1}$ infection in man still remain largely unknown. A pathogenetic role in the clearance of infected hepatocytes has been suggested for nucleocapsid-specific cytolytic $T$ cells based on the finding that

Address correspondence and reprint requests to Dr. Carlo Ferrari, Cattedra Malattie Infettive, Universita' di Parma, 43100 Parma, Via Gramsci 14, 43100 Parma, Italy.

Received for publication 13 August 1990 and in revised form 6 March 1991.

1. Abbreviations used in this paper: AA, amino acid; APC, antigen presenting cell; $\mathrm{HBc}, \mathrm{e}, \mathrm{s} \mathrm{Ag}$, hepatitis $\mathrm{B}$ core, e, surface antigen; HBV, $\mathrm{HB}$ virus; SI, stimulation index.

J. Clin. Invest.

(c) The American Society for Clinical Investigation, Inc.

$0021-9738 / 91 / 07 / 0214 / 09 \$ 2.00$

Volume 88, July 1991, 214-222 autologous liver cells can be apparently lysed in vitro by peripheral blood $\mathrm{T}$ cells and that this phenomenon can be selectively blocked by anti-HBc monoclonal antibodies (1). The possibility that hepatitis B core antigen $(\mathrm{HBcAg})$ represents an important sensitizing antigen for viral-specific $\mathrm{T}$ cells within the liver of patients with chronic HBV infection is also indicated by the recent observation that $\mathrm{CD} 4+$ and $\mathrm{CD} 8+\mathrm{T}$ cells with $\mathrm{HBcAg}$ specific helper and suppressor function respectively, are present in the infected liver at the site of cell injury and viral synthesis $(2,3)$. However, the in vitro HLA class II-restricted peripheral blood $\mathrm{T}$ cell response to nucleocapsid antigens in patients with chronic HBV infection is dramatically lower than that displayed by patients with acute HBV infection (4). This difference may have important pathogenetic implications because appearance of a detectable level of class II-restricted T cell sensitization to nucleocapsid antigens is temporally associated with the clearance of viral particles from sera of subjects with self-limited acute HBV infection (4). The demonstration that $\mathrm{HBcAg}$-specific helper $\mathrm{T}$ cells can directly cooperate in vivo with envelope-specific B cells supporting the production of virus neutralizing anti-envelope antibodies (5) may provide an explanation of this temporal association.

If the development of an adequate immune response to HBV nucleocapsid antigens is actually important for HBV clearance, it follows that identification of immunodominant $T$ cell epitopes within the core molecule could theoretically be useful for the design of more effective alternative vaccines against HBV infection and possibly to plan future strategies to manipulate the immune response to $\mathrm{HBV}$ in subjects who do not spontaneously clear the virus.

In an initial effort to characterize the molecular elements involved in the activation of the different $T$ cell subsets during HBV infection in man, we have studied the proliferative response of peripheral blood $T$ cells from a large group of patients with self-limited acute HBV infection and different genetic backgrounds to a panel of short synthetic peptides covering the entire HBV core region. Our data show that an immunodominant epitope for CD4+ T cells is present within the amino-terminal half of the core molecule (amino acid [AA] 50-69). In addition, two further important sequences are located, one at the aminoterminal end and the other within the carboxyterminal half of the core molecule.

\section{Methods}

Patients. 23 patients (6 females and 17 males) with acute hepatitis B were studied. The diagnosis was based on the finding of elevated values of serum glutamic pyruvic transaminase activity (at least 10 times the upper level of the normal), associated with the detection of IgM anti$\mathrm{HBC}$ antibodies in the serum and the recent onset of jaundice and other typical symptoms of acute hepatitis. All patients recovered completely 
from the illness, with normalization of transaminase and clearance of hepatitis B surface antigen ( $\mathrm{HBsAg})$ from the serum. Control experiments were performed on 20 healthy subjects with no evidence of previous exposure to $\mathrm{HBV}$, i.e., they were negative for $\mathrm{HBsAg}$, antibody to HBsAg (anti-HBs), and antibody to $\mathrm{HBcAg}$ (anti-HBc).

$H B V$ antigens and synthetic peptides. A recombinant preparation of $\mathrm{HBcAg}$ was obtained from bacterial extracts of Escherichia coli $\mathrm{K} 12$ strain HB 101 harboring the recombinant plasmid carrying the $\mathrm{HBcAg}$ coding gene as described previously (6). Purity was $\sim 90 \%$ as determined by scanning densitometry of Coomassie Blue stained SDSpolyacrylamide gel. Human cytoplasmic $\mathrm{HBcAg}(\mathrm{hHBcAg})$ was purified from the liver of a patient on dialysis as described (7). This core preparation had a high $\mathrm{HBcAg}$ activity specifically detected up to a dilution of $1: 2^{11}$ in solid phase radioimmunoassay.

An HBcAg deletion mutant lacking the carboxyl-terminal 39 amino acid residues of the core molecule was produced in $E$. coli and provided by Biogen (Geneva, Switzerland). A detailed characterization of this recombinant antigen has recently been reported (8). Its purity was $99.8 \%$ and it is herein designated as $\mathrm{rHBeAg}$.

18 peptides, $10-20$ residues long, corresponding to the complete sequence of the core and precore region encoded polypeptides (subtype ayw), were synthesized by Multiple Peptide System (La Jolla, CA). Peptides were designed taking into account the amphipathic regions of the antigenic molecules (9) and the presence of consensus motifs based on Rothbard studies (10). Amino acid sequences of the synthetic peptides used in this study and indicated by the amino acid position from the $\mathrm{NH}_{2}$-terminus of the core and precore derived polypeptides are as follows: 1-21, 20-34, 28-47, 38-54, 50-59, 50-64, 50-69, 61-80, 70$89,82-101,100-119,117-131,120-139,131-145,140-155,155-$ 169, 169-183, 20 precore-2 core (Fig. 1).

Isolation of peripheral blood lymphomononuclear cells. PBMC were isolated from fresh heparinized blood by Ficoll-Hypaque density gradient centrifugation. The $T$ cells and non- $T$ cells were separated by rosetting PBMC with 2-aminoethylisothiuronium bromide (AET; Sigma Chemical Co., St. Louis, MO) treated sheep erythrocyte (11). The E-rosette forming $T$ cells were separated from the nonrosetting (non-T) cells by Ficoll-Hypaque gradient. Purity of the $T$ and non- $T$ cell fractions was evaluated by direct immunofluorescence with antiCD3 monoclonal antibody after red cell osmotic lysis. The $T$ cell population contained more than $95 \% \mathrm{CD} 3+$ cells, whereas the nonrosetting fraction contained less than $3 \%$ of $\mathrm{CD} 3+$ cells.

Isolated cell populations were resuspended to $1 \times 10^{6}$ cells $/ \mathrm{ml}$ in RPMI 1640 supplemented with $25 \mathrm{mM}$ Hepes, $2 \mathrm{mM}$ L-glutamine, 50 $\mu \mathrm{g} / \mathrm{ml}$ gentamycin, and $10 \%$ human $\mathrm{AB}$ positive serum (complete medium).

Isolation of HBV nucleocapsid antigen-specific $T$ cell lines. PBMC were cultured in round-bottomed wells of 96-well plates (Costar, Cambridge, MA) in the presence of different concentrations of $\mathrm{HBcAg}$, HBeAg, or synthetic peptides. After $7 \mathrm{~d}$, activated T cells were expanded by adding IL-2. Growing lines were restimulated after an additional 5 to $7 \mathrm{~d}$ with the appropriate $\mathrm{HBV}$ antigen plus irradiated $(3,000$ rad) autologous PBMC $\left(5 \times 10^{5} / \mathrm{ml}\right)$ as antigen presenting cells (APC) in medium supplemented with $20 \mathrm{U} / \mathrm{ml}$ of rIL-2. From this point, colonies were restimulated every $7 \mathrm{~d}$ and were provided with supplementary IL-2-containing medium between restimulations to maintain the cell concentration between $3 \times 10^{5}$ and $1 \times 10^{6} / \mathrm{ml}$.

Proliferation assays. Unfractionated PBMC $\left(2 \times 10^{5} /\right.$ well $)$ were incubated in 96-well microtiter plates (Costar) for $7 \mathrm{~d}$ at $37^{\circ} \mathrm{C}$ in an atmosphere of $5 \% \mathrm{CO}_{2}$ in air in the presence of different concentrations of each HBV antigen or synthetic peptide above described. In selected experiments, purified peripheral blood T cells $\left(1 \times 10^{5}\right)$ were incubated with autologous irradiated $(3,000 \mathrm{rad})$ non-T cells $\left(1 \times 10^{4}\right)$ as APC.

For the study of polyclonal $\mathrm{T}$ cell lines, $\mathrm{T}$ cells were washed extensively to remove IL- 2 and FCS. Subsequently, $5 \times 10^{4}$ cells/well were incubated for $3 \mathrm{~d}$ with $1 \times 10^{5}$ autologous irradiated (3,000 rad) PBMC as APC in complete medium in the presence of different concentrations of HBV antigens or synthetic peptides. All proliferation assays were performed in triplicate and $\left[{ }^{3} \mathrm{H}\right]$ thymidine $(0.5 \mu \mathrm{Ci} /$ well; sp act
2.0 Ci/mM; Amersham International, Amersham, UK) was added 18 $h$ before harvesting. The results are expressed as the mean counts per minute of triplicate determinations. The stimulation index (SI) was calculated as the ratio between mean counts per minute obtained in the presence of antigen to that obtained in the absence of antigen.

$H L A$ restriction of $T$ cell activation. The HLA restriction of peptide recognition by $T$ cells was determined using murine $M A b$ to human HLA class I and class II antigens to inhibit $T$ cell proliferation. The following MAb were used in this study: D1-12 (IgG2a) and E.31 (IgG2a) specific for DR molecules; BT3/4 (IgG1) and SPV-L3 (IgG2a) recognizing DQ molecules; B7/21 (IgG2a) specific for DP antigens; and W6/32 (IgG2a) anti-HLA A, B, C specific. The specificity of these anti-HLA antibodies has previously been described in detail (12-19).

D1-12, BT3/4, and B7/21 MAb were used as hybridoma culture supernatants at $1: 5$ final dilution. This dilution corresponds to an antibody concentration sufficient to give $50 \%$ of maximal binding on Raji lymphoblastoid cell lines and always corresponds to saturating antibody concentration for the APC used in our functional assays. Purified W6/32, E31, and SPV-L3 MAb were used at the concentration of 10 $\mu \mathrm{g} / \mathrm{ml}$.

Anti-HLA class I and anti-HLA class II MAb were incubated overnight with autologous PBMC as APC and the stimulatory peptide. APC were then washed, irradiated, and added to responder peptide-specific $\mathrm{T}$ cell lines. $\left[{ }^{3} \mathrm{H}\right]$ thymidine incorporation was measured after $3 \mathrm{~d}$ of culture.

\section{Results}

PBMC proliferative response to $\mathrm{HBV}$ nucleocapsid synthetic peptides. Patients with acute hepatitis $B$ were chosen for the study of the fine specificity of the T cell response to HBV nucleocapsid antigens since a strong level of $T$ cell response to $\mathrm{HBCAg}$ and $\mathrm{HBeAg}$ is always detectable during the acute phase of HBV infection (4).

The complete panel of 18 synthetic peptide analogs of $\mathrm{HBcAg}$ and $\mathrm{HBeAg}$ used in this study is represented in Fig. 1.

Stimulation of PBMC with the panel of partially overlapping peptides revealed that all acute hepatitis patients responded to at least one T cell epitope (Table I). It is remarkable that all except one (patient 12 of Table I) showed a significant

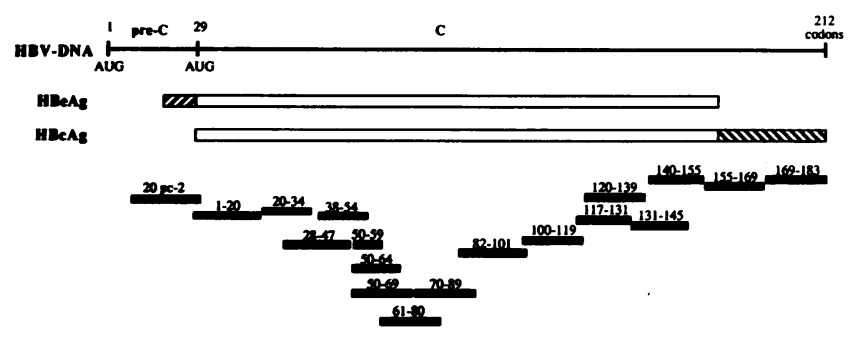

Figure 1. Schematic representation of the synthetic peptides sequences, the $\mathrm{HBcAg}$ and $\mathrm{HBeAg}$ molecules, the HBV core open reading frame. $\mathrm{HBcAg}$ and $\mathrm{HBeAg}$ are both encoded by the core open reading frame (40), which contains two in-frame translation initiation codons separated by an 87 -bp region, designated precore. $\mathrm{HBcAg}$ is synthesized when the second initiation codon is used, whereas the $\mathrm{e}$ protein is probably generated by the cleavage of a precursor polypeptide that is translated from the entire core open reading frame (4143). Production of $\mathrm{HBeAg}$ results from removal of a signal peptide at the amino end of this precursor polypeptide by a signal peptidase and from cleavage of the arginine-rich carboxy end by trypsin-like proteases (44). The hatched portions of the $\mathrm{HBcAg}$ and $\mathrm{HBeAg}$ molecules denote amino acid sequences that are not shared by core and $\mathrm{e}$. 
Table I. PBMC Response to HBcAg Synthetic Peptides in 23 Patients with Acute Hepatitis B

HBc-peptides

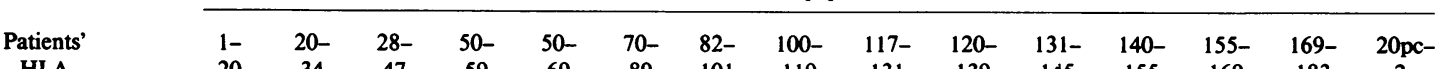

HLA

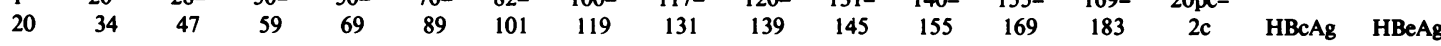

1. DR1, 7, w53

DQw1, w2

$1 \mu \mathrm{g} / \mathrm{ml}$

10

100

2. Drw6, w52

DQw1, w3

$1 \mu \mathrm{g} / \mathrm{ml}$

10

100

3. DR5, w6, w52

$1 \mu \mathrm{g} / \mathrm{ml}$

10

100

4. DR5, 7, w52, w53, DQw2, w3

$1 \mu \mathrm{g} / \mathrm{ml}$

10

100

5. DR2, 5, w52

DQw1, w3

$1 \mu \mathrm{g} / \mathrm{ml}$

10

100

$\begin{array}{lll}- & - & - \\ 11.1 & - & - \\ 14.3 & - & 4.7\end{array}$

$\begin{array}{lll}\text { n.t. } & - & - \\ \text { n.t. } & - & -\end{array}$

n.t.

n.t. - n.t.

9.5

DR3, 7, w52,

w53, DQw2, w3

$1 \mu \mathrm{g} / \mathrm{ml}$

10

100

7. DR3, 5, w52

DQw2, w3

$1 \mu \mathrm{g} / \mathrm{ml}$

10

100

8. DR5, w52

DQw3

$1 \mu \mathrm{g} / \mathrm{ml}$

10

9. DR7, w53

DQw2

$1 \mu \mathrm{g} / \mathrm{ml}$

$\begin{array}{lll}- & - \\ - & - & -\end{array}$

n.t. 5

5.2

n.t. n.t. 3.6 n.t. $-\quad-\quad-$

- - -

n.t. $5.4--\quad-$

n.t. - n.t.

n.t.

- - -

$11.6 \quad 8.4$

- $\quad-\quad-$

n.t. $\quad 3.6-3.5-$

n.t.

n.t.

- - -

n.t. $5.4-3.9-$

n.t.

6.8

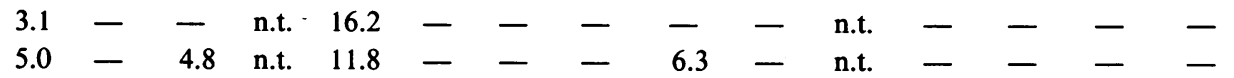

$$
\begin{aligned}
& 6.1-9.3 \text { n.t. } 8.7-\text { - } \quad 9-\text { n.t. }- \text { n.t. }- \text { - }-
\end{aligned}
$$

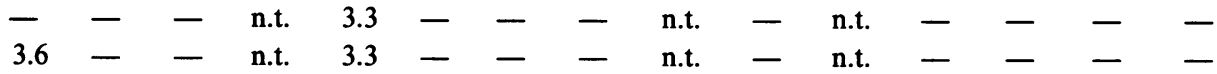

$$
\begin{aligned}
& 4.0-6.0 \text { n.t. } 5.0-\text { n.t. } 4.9 \text { n.t. }- \text { - }-6-
\end{aligned}
$$

\section{4}


HBc-peptides

$\begin{array}{cccccccccccccccccc}\text { Patients' } & 1- & 20- & 28- & 50- & 50- & 70- & 82- & 100- & 117- & 120- & 131- & 140- & 155- & 169- & 20 \mathrm{pc}- & & \\ \text { HLA } & 20 & 34 & 47 & 59 & 69 & 89 & 101 & 119 & 131 & 139 & 145 & 155 & 169 & 183 & 2 \mathrm{c} & \text { HBcAg } & \text { HBeAg }\end{array}$

12. DR3, w11,

w52, DQw2, w3

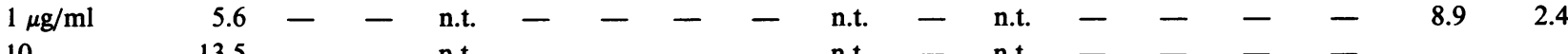

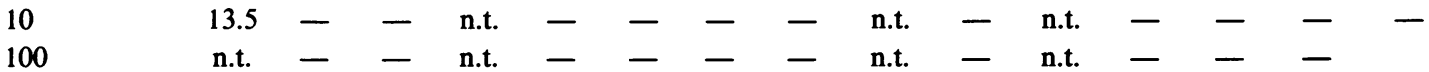

13. DR5, 10, w52

DQw1, w3

$1 \mu \mathrm{g} / \mathrm{ml}$

10

100

14. DR2, w6,

w52, DQw1

$1 \mu \mathrm{g} / \mathrm{ml}$

10

100

15. DR3, 5, w52

DQw2, w3

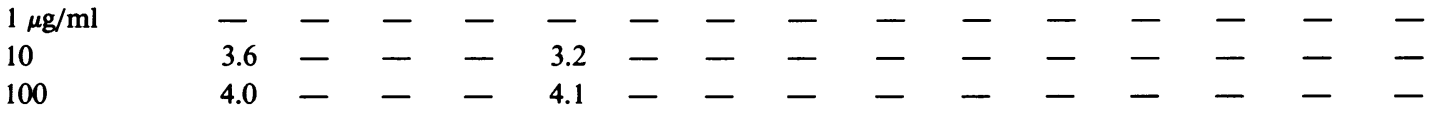

16. DR4, w53

$$
6.3-7-7.5-7.3-9.3-6-13.2
$$

Qw3

$1 \mu \mathrm{g} / \mathrm{ml}$

10

100

17. DR3, w52

DQw2

$1 \mu \mathrm{g} / \mathrm{ml}$

10

100

18. DR3, w6, w52

DQw1, w2

$1 \mu \mathrm{g} / \mathrm{ml}$

10

100

19. DR5, w6, w52

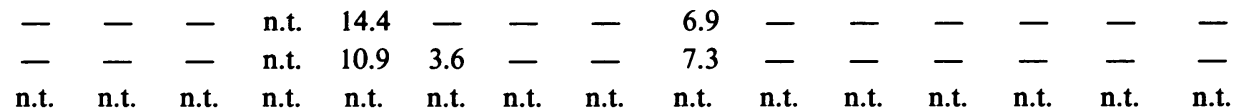

DQw1, w3

$1 \mu \mathrm{g} / \mathrm{ml}$

10

100

$8.1-7.5-8.3-6.9-14.9-6.6-$

20. DR3, w52

DQw2

$1 \mu \mathrm{g} / \mathrm{ml}$

10

100

21. DR 1, 2

DQw1

$1 \mu \mathrm{g} / \mathrm{ml}$

10

100

22. DR5, w6, w52

DQw1, w3

$1 \mu \mathrm{g} / \mathrm{ml}$

10

100

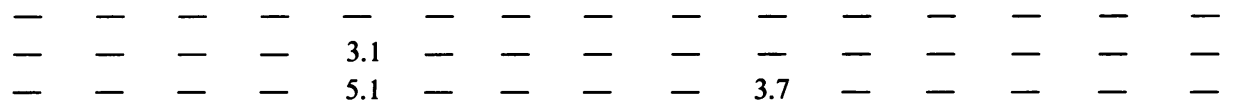

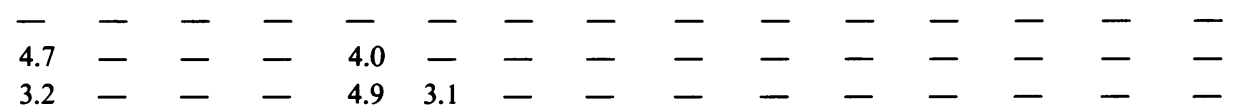

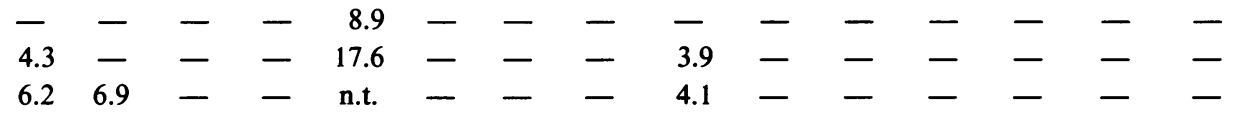

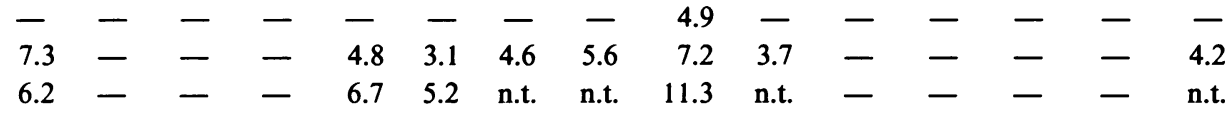

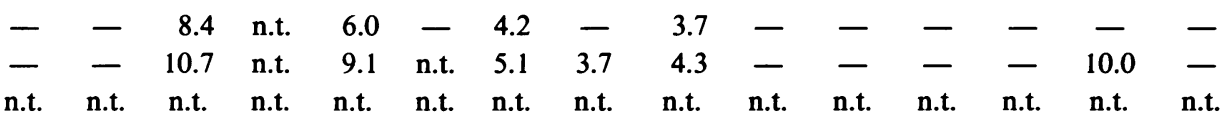

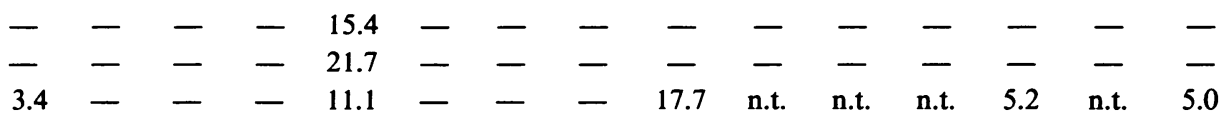




\begin{tabular}{|c|c|c|c|c|c|c|c|c|c|c|c|c|c|c|c|c|c|}
\hline \multirow[b]{2}{*}{$\begin{array}{l}\text { Patients' } \\
\text { HLA }\end{array}$} & \multicolumn{15}{|c|}{ HBc-peptides } & \multirow[b]{2}{*}{ HBcAg } & \multirow[b]{2}{*}{ HBeAg } \\
\hline & $\begin{array}{l}1- \\
20\end{array}$ & $\begin{array}{c}20- \\
34\end{array}$ & $\begin{array}{l}28- \\
47\end{array}$ & $\begin{array}{c}50- \\
59\end{array}$ & $\begin{array}{c}50- \\
69\end{array}$ & $\begin{array}{c}70- \\
89\end{array}$ & $\begin{array}{l}82- \\
101\end{array}$ & $\begin{array}{l}100- \\
119\end{array}$ & $\begin{array}{c}117- \\
131\end{array}$ & $\begin{array}{c}120- \\
139\end{array}$ & $\begin{array}{c}131- \\
145\end{array}$ & $\begin{array}{c}140- \\
155\end{array}$ & $\begin{array}{c}155- \\
169\end{array}$ & $\begin{array}{c}169- \\
183\end{array}$ & $\begin{array}{l}20 \mathrm{pc}- \\
2 \mathrm{c}\end{array}$ & & \\
\hline \multicolumn{18}{|l|}{ 23. DR3, w52 } \\
\hline \multicolumn{18}{|l|}{ DQw2 } \\
\hline $1 \mu \mathrm{g} / \mathrm{ml}$ & - & - & - & - & 3.6 & - & - & - & 4.5 & - & - & - & - & - & - & 8.5 & 12.5 \\
\hline 10 & 9.7 & - & 4.8 & - & 3.3 & - & - & 3.4 & 4.6 & - & - & - & - & - & - & & \\
\hline 100 & 12.1 & - & 6.6 & - & 6.0 & 5.4 & - & 7.5 & 5.6 & n.t. & n.t. & n.t. & n.t. & n.t. & n.t. & & \\
\hline
\end{tabular}

PBMC $\left(2 \times 10^{5} /\right.$ well $)$ were cultured in the presence of the indicated peptide concentrations and proliferation was measured as $\left[{ }^{3} \mathrm{H}\right]$ thymidine incorporation. Results are expressed as stimulation index which is the ratio between mean counts per minute obtained in the presence of antigen and those obtained in the absence of antigen. The proliferative response induced by $1 \mu \mathrm{g} / \mathrm{ml}$ of $\mathrm{hHBcAg}$ and $\mathrm{rHBeAg}$ is also indicated. Stimulation indexes higher than three were considered as significant values of proliferative response. Values of ${ }^{3} \mathrm{H}-\mathrm{TdR}$ incorporation by PBMC in the absence of antigen or peptides were usually less than $2,000 \mathrm{cpm}$. No significant levels of PBMC proliferation to core peptides were observed in the normal control population. - , No proliferative responses at any of the tested concentrations. n.t., Not tested.

level of $\mathrm{T}$ cell response to the 50-69 sequence irrespective of the HLA haplotype. Concentrations of this peptide as low as $0.01 \mu \mathrm{g} / \mathrm{ml}$ were stimulatory for PBMC of several patients (data not shown).

Two additional important sequences were also identified at the amino-terminal end and within the carboxy-terminal half of the core molecule. The 1-20 sequence was recognized by 16 of 23 patients $(69 \%)$ and the $117-131$ sequence was able to induce significant levels of PBMC proliferation in 11 of 15 patients studied (73\%). Minor T cell sites which were stimulatory for a few patients at high peptide concentrations were amino acid sequences 20-34, 28-47, 70-89, 82-101, 100-119, $140-155,169-183,20 \mathrm{pc}-2 \mathrm{c}$.

On a weight basis, the whole core protein was more efficient than the synthetic peptides in the stimulation of the $T$ cell response in most of the patients (Table I), and the difference between HBcAg and peptides was even higher on a molar basis because $1 \mu \mathrm{g} / \mathrm{ml}$ of $\mathrm{HBcAg}$ corresponds to $0.045 \mu \mathrm{M}, 1 \mu \mathrm{g} / \mathrm{ml}$ of peptide $1-20$ to $0.385 \mu \mathrm{M}, 1 \mu \mathrm{g} / \mathrm{ml}$ of peptide $50-69$ to 0.382 $\mu \mathrm{M}$, and $1 \mu \mathrm{g} / \mathrm{ml}$ of peptide $117-131$ to $0.502 \mu \mathrm{M}$.

This weaker peptide-induced proliferation with respect to that to native $\mathrm{HBcAg}$ suggests that multiple distinct epitopes are responsible for the proliferative response to $\mathrm{HBcAg}$ in a single individual or that the processing of native $\mathrm{HBcAg}$ yields peptides that are related to but not identical with the synthetic peptides, thereby inducing cross-reactive $\mathrm{T}$ cells with higher affinity for the endogenously processed determinants.

Fractionation experiments performed with purified populations of $T$ and non-T cells showed that unfractionated PBMC and purified $T$ cells (cocultured with autologous irradiated non- $T$ cells as APC) express similar dose-response curves when stimulated with the core peptide analog 50-69 (data not shown).

The observation that peptides corresponding to core sequences 38-54, 50-59, and 50-64 were not stimulatory for $\mathrm{T}$ cells from five different patients responsive to peptide 50-69 (Fig. 2) suggests that critical residues required for T cell activation are likely contained, at least for these patients, within the COOH-terminal end of the peptide. This is apparently confirmed in two subjects by the significant level of $T$ cell stimulation induced by peptide $61-80$ (Fig. 2). Further examination of this likelihood is in progress, at the clonal level, using truncated and substituted analogue peptides.

Most of the patients who showed a significant proliferative response to the 117-131 sequence did not recognize the 120139 and 100-119 sequences, suggesting that $T$ cell recognition of the 117-131 peptide is probably focussed on its $\mathrm{NH}_{2}$-terminal portion. In contrast, in two patients, all three peptides (117-131, 100-119, 120-139) were simultaneously recognized (patients 8 and 20; Table I), implying that more than one T cell site is probably contained in the core region ranging from residue 100 to 139 .

$T$ cell response to the relevant core peptide analogues is temporally associated with the $T$ cell response to the native $\mathrm{HBCAg}$ molecule. 10 patients were studied prospectically during the symptomatic period and during convalescence for PBMC proliferation in response to native nucleocapsid antigens and synthetic peptide analogues. The presence of a significant proliferative response to the core peptides was always asso-

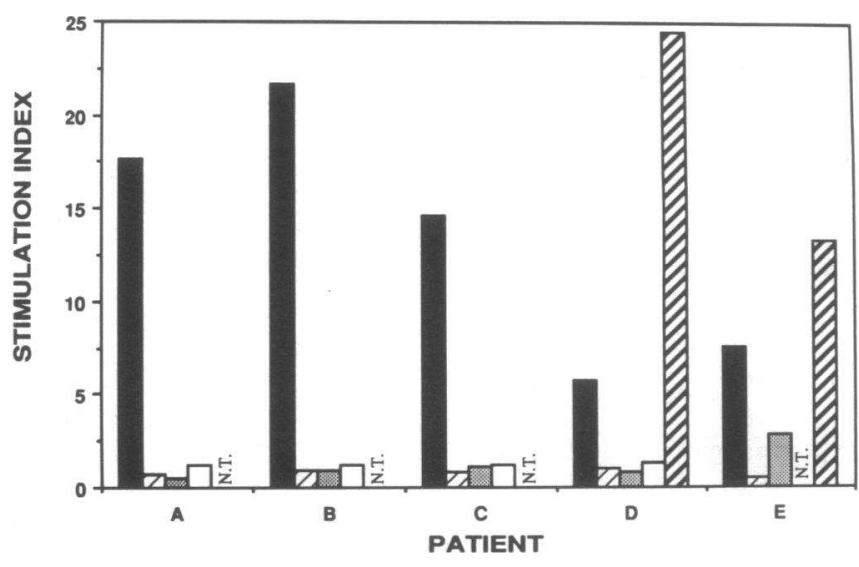

Figure 2. PBMC proliferative response to peptide 50-69 (ם), 50-59

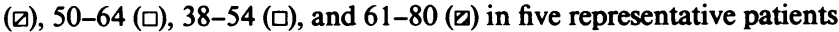
with acute hepatitis B. PBMC were stimulated with $10 \mu \mathrm{g} / \mathrm{ml}$ of peptide and $\left[{ }^{3} \mathrm{H}\right]$ thymidine incorporation was measured after $7 \mathrm{~d}$ of culture. ${ }^{3} \mathrm{H}$-TdR incorporation by PBMC in the absence of peptide was $2949,1075,389,527$, and $970 \mathrm{cpm}$ for patients A, B, C, D, and E, respectively. $\mathrm{N}$. T., not tested. 


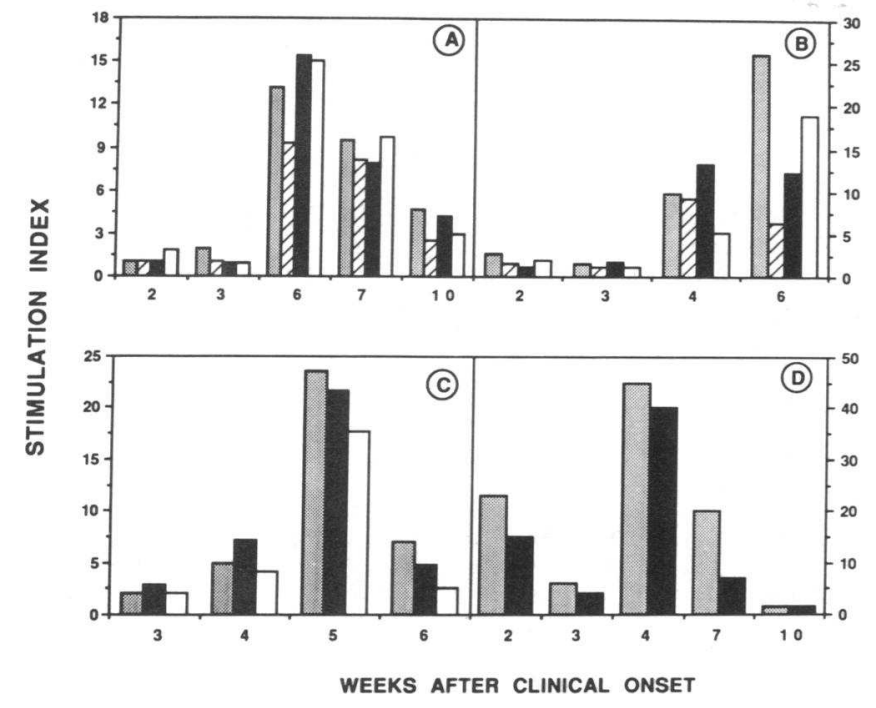

Figure 3. Serial determinations of the PBMC proliferative response to $\mathrm{HBcAg}(\square)$ and to the relevant core peptides ( $\square$, peptide 1-20; $a$, peptide $50-69 ; \square$ peptide $117-131$ ) at different times during the course of the acute HBV infection in four representative patients. Data correspond to antigen concentrations that gave maximum SI. Mean values of $\mathrm{SI} \pm \mathrm{SD}$ with control $\mathrm{PBMC}$ were: $\mathrm{HBcAg}=1.5 \pm 0.5$; peptide $1-20$ $=1.1 \pm 0.51$; peptide $50-69=1.4 \pm 0.8$; peptide $117-131=1.1 \pm 0.7$. ${ }^{3} \mathrm{H}-\mathrm{TdR}$ incorporation in the negative control cultures was usually lower than 2,000 cpm. Patients represented in panel A, B, C, and D correspond to patients $14,9,22$, and 8 of Table I, respectively.

ciated with the detection of a significant response to the native core protein, suggesting that amino acid sequences contained within these peptides probably represent the products of the nucleocapsid processing involved in the activation of core-specific T cells (Fig. 3). In three of these patients the T cell responsiveness to peptide 50-69 was only transient because it became undetectable when $T$ cells were still able to respond to the native $\mathrm{HBcAg}$ (data not shown). This implies that for a minority of subjects the amino acid sequence 50-69 does not represent the major $\mathrm{T}$ cell epitope within the core molecule.

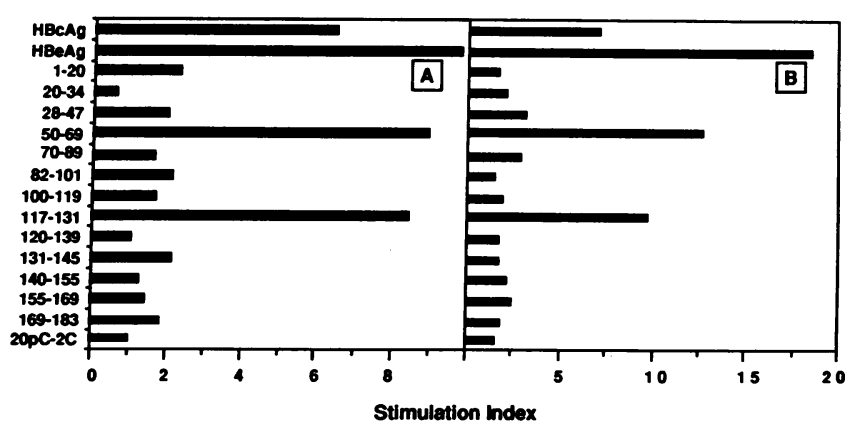

Figure 4. Proliferative response to $1 \mu \mathrm{g} / \mathrm{ml}$ of $\mathrm{HBcAg}, \mathrm{HBeAg}$, and synthetic peptides of two representative polyclonal $\mathrm{T}$ cell lines produced by PBMC stimulation (patient 14 of Table I) either with $\mathrm{HBcAg}(A)$ or with $\mathrm{HBeAg}(B)$. For the production of $\mathrm{HBV}$ nucleocapsid-specific $\mathrm{T}$ cell lines see Methods. Values of ${ }^{3} \mathrm{H}-\mathrm{TdR}$ incorporation in the absence of antigen were $386 \mathrm{cpm}$ for the $\mathrm{T}$ cell line represented in $A$ and $506 \mathrm{cpm}$ for the T cell line in $B$.

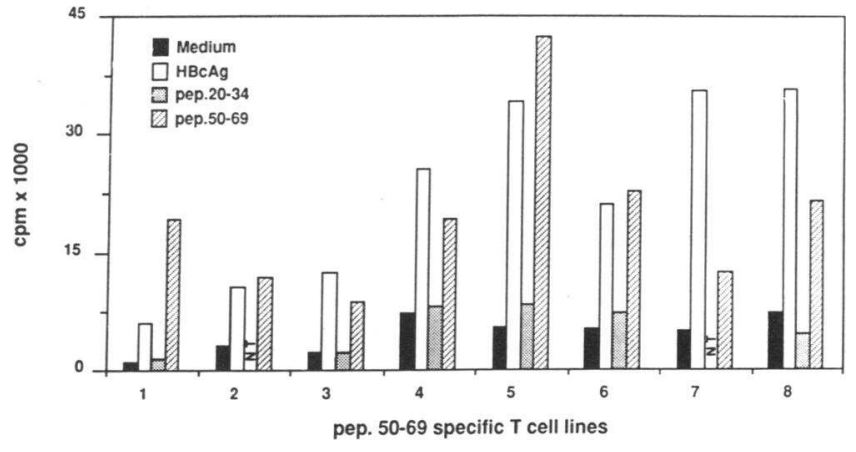

Figure 5. Proliferative response to $1 \mu \mathrm{g} / \mathrm{ml}$ of $\mathrm{HBcAg}$, peptide 50-69 and an irrelevant peptide (20-34) of eight polyclonal T cell lines produced from different acute patients by PBMC stimulation with peptide 50-69. The concentration of peptide 50-69 used for the generation of the polyclonal $\mathrm{T}$ cell lines was $0.1 \mu \mathrm{g} / \mathrm{ml}$. pep., Peptide.

Amino acid sequences identified by the stimulatory peptides represent immunodominant core epitopes. To further investigate whether the stimulatory core peptides actually contain amino acid sequences of the core molecule recognized by nucleocapsid-specific $\mathrm{T}$ cells, $\mathrm{HBcAg}$ - and $\mathrm{HBeAg}$-specific polyclonal $\mathrm{T}$ cell lines were produced from five patients by PBMC stimulation with native antigen and IL-2. T cell lines specifcally reactive to $\mathrm{HBcAg}$ and $\mathrm{HBeAg}$, but not to other $\mathrm{HBV}$ antigens (envelope antigens; data not shown), only displayed significant levels of proliferation in the presence of the relevant peptides recognized by autologous PBMC (Fig. 4). In the reciprocal experiment, polyclonal $\mathrm{T}$ cell lines produced by PBMC stimulation with the relevant synthetic peptides were able to recognize the native core molecule (Figs. 5 and 6), confirming that the stimulatory amino acid sequences represented by the synthetic peptides are actually available after processing of the native core molecule. $T$ cell recognition of core peptides was HLA class II restricted because peptide-induced proliferation of polyclonal $\mathrm{T}$ cell lines was significantly inhibited by antiHLA class II monoclonal antibodies, but not by an anti-HLA

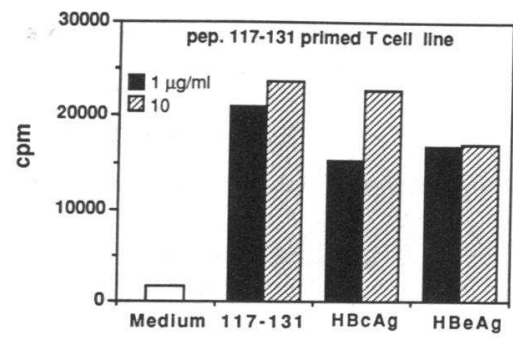

Figure 6. Peptide 1-20 and peptide 117-131 specific $T$ cell lines can recognize the whole $\mathrm{HBcAg}$ and $\mathrm{HBeAg}$ molecules. $T$ cell lines were produced from patient 23 of Table I as described in Methods and tested with different concentrations of $\mathrm{HBcAg}, \mathrm{HBeAg}$, and the relevant sensitizing peptide. pep., Peptide. 


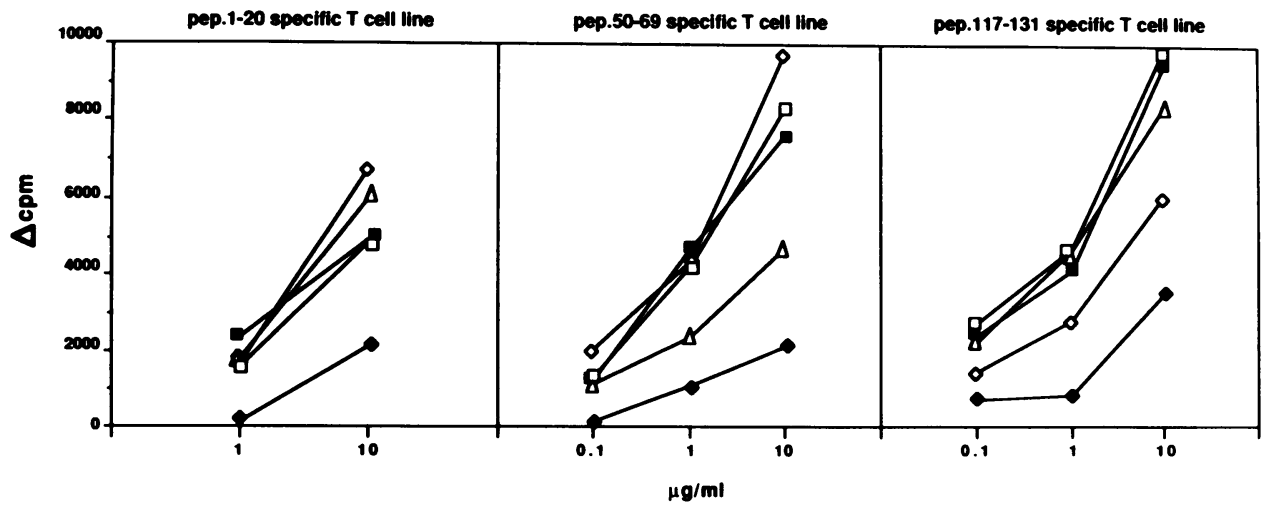

Figure 7. HLA restriction of peptide-induced $\mathrm{T}$ cell proliferation. Autologous APC were incubated overnight without (ם) or with antiHLA class I (W6/32, $\square$ ) and antiHLA class II (D1-12 anti-DR, $\bullet)$ (B7/21 anti-DP, $\Delta$ ) (BT 3/4 anti-DQ, $\diamond)$ monoclonal antibodies and synthetic peptides. After washing and irradiation, APC were added to T cells from three representative peptide-primed polyclonal $\mathrm{T}$ cell lines (1-20, 50-69, and 117-131 specific) and $\left[{ }^{3} \mathrm{H}\right]$ thymidine incorporation was measured 3 d later. A 50-69 specific T cell line was also tested with different anti-HLA DR (E.31) and anti-HLA DQ (SVP-L3) MAb with similar results (data not shown). pep., Peptide.

class I monoclonal antibody (Fig. 7). In addition, phenotypic analysis of 14 polyclonal $\mathrm{T}$ cell lines produced by PBMC stimulation with $1-20,50-69$, and $117-131$ core sequences showed that $\mathrm{T}$ cell lines were almost exclusively CD4+ (more than $80 \%$ ).

\section{Discussion}

It is well recognized that antienvelope antibodies can neutralize viral particles and, thereby, can confer protection against HBV infection (20). Based on this evidence, vaccines consisting of $\mathrm{HBsAg}$ purified from plasma of chronic $\mathrm{HBsAg}$ carriers or produced by recombinant DNA technology have been developed and proved to be highly effective in preventing $\mathrm{HBV}$ infection $(21,22)$. Though a protective antibody response is usually induced by the currently licensed $\mathrm{HBsAg}$ vaccines in more than $90 \%$ of healthy persons, the proportion of nonresponders is much higher among hemodialysis patients and other immunocompromised persons. For effective immunity these patients require an increased number of doses and a larger amount of immunogen $(23,24)$.

In an attempt to produce vaccines with enhanced immunogenic potential, inclusion of preS sequences of the HBV envelope in the HBsAg-based vaccine has been proposed (25-28). The HBV nucleocapsid antigen also represents a good candidate for the development of more immunogenic anti-HB vaccines for several reasons. First, $\mathrm{HBcAg}$ is a very powerful $\mathrm{T}$ cell immunogen (29). Second, HBcAg-specific helper T cells can support antienvelope antibody production by HBV envelopespecific B cells (5) and, thus, may play a central role in viral clearance. Third, $\mathrm{HBcAg}$ is an important sensitizing antigen for intrahepatic $\mathrm{T}$ cells during chronic $\mathrm{HBV}$ infection $(2,3)$ and it is thought to represent a target structure for the immune-mediated injury of infected hepatocytes (1). Fourth, immunization of chimpanzees and woodchucks with nucleocapsid antigen $(\mathrm{HBcAg}$ or $\mathrm{WHcAg}$ ) provides complete or partial protection against $\mathrm{HBV}$ and WHV infection (30-33). Fifth, $\mathrm{HBcAg}$ can function as a carrier and adjuvant for other antigens (34, 35). Sixth, HBcAg is a T cell-dependent and -independent B cell immunogen (29).

To identify the amino acid sequences within the core molecule that are involved in the activation of nucleocapsid-specific $\mathrm{T}$ cells during $\mathrm{HBV}$ infection in man and to explore the feasibil- ity of a synthetic HB vaccine including relevant core epitopes, we have analyzed the fine specificity of the $T$ cell response to HBcAg using a panel of short synthetic peptides covering the entire $\mathrm{HBV}$ core region.

Analysis of patients with acute $\mathrm{HBV}$ infection and different HLA haplotypes reveals that several sequences within the core molecule can induce significant levels of $T$ cell response in $\mathrm{HBcAg}$-sensitized individuals, as previously reported in the mouse system (36). In addition, more than one peptide fragment is usually recognized by $T$ cells of individual patients.

However, the most relevant finding of our study is the identification of an immunodominant amino acid sequence (residues 50-69) which was recognized by all but one patient (95\%). Remarkably, concentrations of peptide as low as $10 \mathrm{ng} / \mathrm{ml}$ are sufficient to elicit a significant in vitro $\mathrm{T}$ cell response in several subjects (not shown).

Data derived from $\mathrm{T}$ cell stimulation with truncated and overlapping analogues of the 50-69 peptide show that the critical residues involved in $\mathrm{T}$ cell activation are likely located within the $\mathrm{COOH}$-terminal region of the sequence. Interestingly, residues 64-67 (ELMT) correspond to the sequence motif, described by Rothbard et al., as being common to several T cell epitopes (10).

A significant proportion of $\mathrm{T}$ cells from different patients were also able to respond to two additional peptides corresponding to amino acids $1-20$ and $117-131$ of the core molecule ( 69 and $73 \%$ of the analyzed patients, respectively). The single patient who did not recognize peptide 50-69 displayed a strong $\mathrm{T}$ cell response to peptide 1-20 (patient 12, Table I). This suggests that peptides $1-20$ and 50-69 are capable of inducing significant $\mathrm{T}$ cell responses in all $\mathrm{HBcAg}$-sensitized patients irrespective of their genetic background.

Our results partially differ from those reported by Milich et al. (36) who showed that the fine specificity of the murine T cell response to $\mathrm{HBcAg}$ is much more dependent on the MHC haplotype of the responder strain. In addition, the immunodominant $T$ cell epitope located within residues 50-69 was not identified and also the murine $\mathrm{T}$ cell epitope represented by peptide $120-140$ in Milich's study is probably contiguous but distinct from the dominant epitope for human $T$ cells identified by peptide $117-131$.

Although these synthetic peptides efficiently induce $T$ cell activation in vitro, they need not represent the $\mathrm{HBcAg}$ frag- 
ments generated by the intracellular processing of the core molecule that are recognized by $\mathrm{HBcAg}$-specific $\mathrm{T}$ cells during natural infection. Three additional lines of evidence, however, show that peptides 1-20,50-69, and 117-131 do contain amino acid residues generated by $\mathrm{HBcAg}$ processing relevant to the activation of a $\mathrm{HBcAg}$-specific $\mathrm{T}$ cell response. First, the time of appearance of a significant $\mathrm{T}$ cell response to core peptides during the course of $\mathrm{HBV}$ infection is always associated with the time of appearance of the response to the native core antigen. Second, antigen-specific $\mathrm{T}$ cell lines produced by PBMC stimulation with $\mathrm{HBcAg}$ or $\mathrm{HBeAg}$ can be restimulated not only with the native nucleocapsid proteins but also with the relevant peptide analogs recognized by autologous PBMC. Finally, peptide-primed polyclonal T cell lines selected by PBMC stimulation with a single core peptide can react with the whole core protein. Collectively, these results demonstrate that immunodominant AA sequences generated by the processing of the native core molecule are contained within the synthetic peptides 1-20, 50-69, and 117-131.

Amino acid sequences 1-20,50-69, and 117-131 appear to preferentially activate $\mathrm{CD} 4+\mathrm{T}$ cells which recognize peptide fragments in the context of HLA class II molecules as shown by blocking experiments with anti-HLA monoclonal antibodies and phenotypic analysis of peptide-primed polyclonal $\mathrm{T}$ cell lines. Due to the limited life time and the poor growth capacity of the polyclonal $\mathrm{T}$ cell lines, identification of the specific HLA molecules capable of associating with peptide 50-69 was not possible. However, the observation that this peptide is recognized by most $\mathrm{HBcAg}$-responsive patients suggests that it can efficiently bind to many different HLA alleles, as already reported for other peptides in different systems (37-39). In addition, the simultaneous inhibition of the proliferative response to the relevant core peptides obtained with anti-DR, anti-DP, and anti-DQ monoclonal antibodies probably means that different subsets of HLA class II molecules can serve as restriction elements for a single peptide. Clonal analysis of the $\mathrm{T}$ cell response to peptide 50-69 in different patients is required to address these important questions.

Peptides 1-20, 50-69, and 117-131 are not recognized by anti-HBc antibodies. This is shown by experiments in which the core peptides used to study the fine specificity of the $T$ cell response were also used as solid phase antigens to detect anti$\mathrm{HBc}$ antibodies in sera of six patients with acute and four with chronic HBV infection by an enzyme-linked immunosorbent assay (data not shown). In addition, competition experiments were performed to test the ability of the core synthetic peptides to inhibit the binding of anti- $\mathrm{HBc}$ positive sera to $\mathrm{HBcAg}$ coated plates (data not shown). No specific binding between peptides and anti-HBc antibodies from patients at different stages of $\mathrm{HBV}$ infection was observed, suggesting either that B cell recognition of the core molecule is focussed on linear amino acid sequences which are missing in our panel of peptides or that antibody recognition of $\mathrm{HBcAg}$ is mostly conformational.

An important biological issue is whether $\mathrm{HBcAg}$ and $\mathrm{HBeAg}$ are recognized by $\mathrm{T}$ cells as distinct antigenic entities. The $\mathrm{T}$ cell response to $\mathrm{HBeAg}$ during acute $\mathrm{HBV}$ infection was usually less vigorous than the $\mathrm{T}$ cell response to $\mathrm{HBcAg}$ (Table I, Fig. 6). This may be related to the particulate nature of $\mathrm{HBcAg}(8)$, which could be more efficiently internalized by the $\mathrm{APC}$, as suggested by the higher concentrations of $\mathrm{HBeAg}$ often required to induce levels of $T$ cell activation similar to those induced by $\mathrm{HBcAg}$ (Fig. 6, lower panel). In addition, it could also be a reflection of a different efficiency of the intracellular processing because $\mathrm{HBeAg}$ and $\mathrm{HBcAg}$ are conformationally different even though they share a large portion of their linear sequence. Finally, it is also possible that $\mathrm{T}$ cell epitopes are present within the carboxyterminal region of $\mathrm{HBcAg}$ (which is not present in the circulating $\mathrm{HBeAg}$ ) as indicated by $\mathrm{T}$ cell recognition of peptide $169-183$ in a proportion of patients (Table I).

However, the observation that the immunodominant $T$ cell epitopes identified in this study are located in the portion of the nucleoprotein molecule common to both $\mathrm{HBcAg}$ and $\mathrm{HBeAg}$ confirms that for human $\mathrm{T}$ cells as well, core and $\mathrm{e}$ antigens are cross-reactive, as already suggested for murine T cells (36).

In conclusion, our study indicates the existence of an immunodominant T cell epitope (AA 50-69) within the core molecule that is recognized by more than $95 \%$ of patients with acute HBV infection and different HLA haplotypes. Two additional important $T$ cell recognition sites were also identified at the aminoterminal end and within the carboxyterminal half of the core molecule. Taken together, these data show that two short amino acid sequences of the core molecule can induce $T$ cell responses in $100 \%$ of patients with acute $\mathrm{HBV}$ infection and different genetic backgrounds. These $T$ cell epitopes physically linked to HBV envelope particles might be exploited to enhance the immunogenicity of the existing HBV envelope-based vaccines and to try to overcome tolerance to $\mathrm{HBsAg}$ particles in nonresponder vaccine recipients. In addition, the immunodominant $\mathrm{T}$ cell epitopes identified within the core molecule represent a good candidate for the design of alternative totally synthetic vaccines. Whether this finding may also be useful for therapeutic strategies directed to manipulate the immune response to $\mathrm{HBV}$ in subjects with chronic $\mathrm{HBV}$ infection remains to be investigated.

\section{Acknowledgments}

Authors would like to thank Biogen S.A., Geneva, Switzerland, for providing $\mathrm{rHBeAg}$; Sorin Biomedica SpA, Saluggia, Italy, for supplying rHBcAg; Marie Anne Petit, INSERM U 131, Clamart, France, for hHBcAg; Roberto Accolla, University of Verona, Italy, and Francesco Sinigaglia, Hoffmann-LaRoche, Basel, Switzerland, for the generous gift of anti-HLA monoclonal antibodies; Luciano Adorini, Preclinical Research, Sandoz, Basel, Switzerland, for helpful discussion; Cytel Corporation, La Jolla, CA, for providing peptide 61-80. Dr. A. Cavalli is supported by Clonit SpA, Milano, Italy. This work was supported in part by the National Institutes of Health, Grants AI-26626, AI-20001, and RR-00833, and by the Ministry of the National Education, Project Liver Cirrhosis, Italy. This is publication No. 6465-MEM from the Research Institute of Scripps Clinic, La Jolla, CA.

\section{References}

1. Mondelli, M., G. Mieli-Vergani, A. Alberti, D. Vergani, B. Portmann, A. L. W. F. Eddleston, and R. Williams. 1982. Specificity of T lymphocyte cytotoxicity to autologous hepatocytes in chronic hepatitis B virus infection: evidence that $T$ cells are directed against HBV core antigen expressed on hepatocytes. $J$. Immunol. 129:2773-2777.

2. Ferrari, C., A. Penna, T. Giuberti, M. J. A. Tong, E. Ribera, F. Fiaccadori, and F. V. Chisari. 1987. Intrahepatic, nucleocapsid antigen-specific $T$ cells in chronic active hepatitis B. J. Immunol. 139:2050-2058.

3. Ferrari, C., M. U. Mondelli, A. Penna, F. Fiaccadori, and F. V. Chisari. 1987. Functional characterization of cloned intrahepatic, hepatitis B virus nucleoprotein-specific helper T cell lines. J. Immunol. 139:539-544. 
4. Ferrari, C., A. Penna, A. Bertoletti, A. Valli, A. Degli Antoni, T. Giuberti, A. Cavalli, M. A. Petit, and F. Fiaccadori. 1990. Cellular immune response to hepatitis B virus (HBV) encoded antigens in acute and chronic $\mathrm{HBV}$ infection. $J$. Immunol. 145:3442-3449.

5. Milich, D. R., A. McLachlan, G. B. Thornton, and J. L. Hughes. 1987. Antibody production to the nucleocapsid and envelope of the hepatitis B virus primed by a single synthetic T cell site. Nature (Lond.). 329:547-549.

6. Pasek, M., T. Goto, W. Gilbert, B. Zink, H. Shaller, P. Mackay, G. Leadbetter, and K. Murray. 1979. Hepatitis B virus genes and their expression in E. Coli. Nature (Lond.). 282:575-579.

7. Petit, M. A., and J. Pillot. 1985. $\mathrm{HBc}$ and $\mathrm{HBe}$ antigenicity and DNA binding activity of major core protein P22 in hepatitis B virus core particles isolated from the cytoplasm of human liver cells. J. Virol. 53:543-551.

8. Milich, D. R., A. McLachlan, S. Stahl, P. Wingfield, G. B. Thorton, J. L. Hughes, and J. E. Jones. 1988. Comparative immunogenicity of hepatitis B virus core and e antigens. J. Immunol. 141:3617-3624.

9. DeLisi, C., and J. A. Berzofsky. 1985. T-cell antigenic sites tend to be amphipatic structures. Proc. Natl. Acad. Sci. USA. 82:7048-7052.

10. Rothbard, J., and W. R. Taylor. 1988. A sequence pattern common to T cell epitopes. EMBO (Eur. Mol. Biol. Organ.) J. 7:93-100.

11. Saxon, A., J. Feldhaus, and R. A. Robins. 1976. Single step separation of human T and B cells using AET-treated sheep red cells. J. Immunol. Methods. 12:285-290.

12. Accolla, R. S., N. Gross, S. Carrel, and G. Corte. 1981. Distinct forms of both alpha and beta subunits are present in the human Ia molecular pool. Proc. Natl. Acad. Sci. USA. 78:4549-4553.

13. Accolla, R. S. 1984. Analysis of the structural heterogeneity and polymorphism of human Ia antigens. Four distinct subsets of molecules are coexpressed in the Ia pool of both DR 1,1 homozygous and DR 3,W6 heterozygous B cell lines. $J$. Exp. Med. 159:378-388.

14. Corte, G., F. Calabi, G. Damiani, A. Bargellesi, R. Tosi, and R. Sorrentino. 1981. Human Ia molecules carrying DC1 determinants differ in both alpha and beta-subunits from Ia molecules crrying la determinants. Nature (Lond.). 292:357-361.

15. Watson, A. J., R. De Mars, I. S. Trowbridge, and F. H. Bach. 1983. Detection of a novel human class II HLA antigen. Nature (Lond.). 304:358-361.

16. Brodsky, F. M., and P. Parham. 1982. Monomorphic anti-HLA-A, B, C monoclonal antibodies detecting molecular subunits and combinatorial determinants. J. Immunol. 128:129-137.

17. Trucco, M. M., G. Garotta, J. W. Stocker, and R. Ceppellini. 1979. Murine monoclonal antibodies against HLA structures. Immunol. Rev. 47:219-252.

18. Crumpton, M. J., J. G. Bodmer, W. F. Bodmer, J. M. Heyes, J. Lindsay, and C. E. Rudd. 1984. 6-11 May, Munich, West Germany, and 13-15 May Vienna, Austria. Biochemistry of class II antigens: workshop report. In Histocompatibility Testing 1984 . E. D. Albert, M. P. Baur, and W. R. Mayr, editors Springer-Verlag Berlin Heidelberg New York Tokyo. 29-37.

19. Spitz, H., J. Borst, M. Giphart, J. Coligan, C. Terhorst, and J. De Vries. 1984. HLA-DC antigens van serve as recognition elements for human cytotoxic T lymphocytes. Eur. J. Immunol. 14:299-304.

20. Beasley, R. P., L. Y. Hwang, C. E. Stevens, C. C. Lin, F. J. Hsieh, K. J. Wang, T. S. Sun, and W. Szmuness. 1983. Efficacy of hepatitis B immune globuli for prevention of perinatal transmission of the hepatitis B virus carrier state: final report of a randomized double-blind, placebo-controlled trial. Hepatology. 3:135-141.

21. Szmuness, W., C. E. Stevens, E. J. Harley, E. A. Zang, W. R. Oleszko, D. C. Williams, R. Sadovsky, J. M. Morrison, and A. Kellner. 1980. Hepatitis B vaccine: demonstration of efficacy in a controlled clinical trial in a high-risk population in the United States. N. Engl. J. Med. 303:833-841.

22. Szmuness, W., C. E. Stevens, E. A. Zang, E. J. Harley, and A. Kellner 1981. Controlled clinical trial on the efficiency of the hepatitis vaccine (Heptavax B): a final report. Hepatology. 5:377-385.

23. Stevens, C. E., H. J. Alter, P. E. Taylor, E. A. Zang, E. J. Harley, W. Szmuness, and the dialysis vaccine trial study group. 1984. Hepatitis B vaccine in patients receiving hemodialysis. Immunogenicity and efficacy. $N$. Engl. J. Med. 311:496-501.

24. Collier, A. C., L. Corey, V. L. Murphy, and H. H. Handsfield. 1988 Antibody to human immunodeficiency virus and suboptimal response to hepatitis B vaccination. Ann. Intern. Med. 109:101-105.
25. Milich, D. R., G. B. Thornton, A. R. Neurath, S. B. H. Kent, M. L. Michel, P. Tiollais, and F. V. Chisari. 1985. Enhanced immunogenicity of the pre-S region of the hepatitis B surface antigen. Science (Wash. DC). 228:11951199.

26. Milich, D. R., A. McLachlan, F. V. Chisari, S. B. H. Kent, and G. B. Thornton. 1986. Immune response to the pre-S(1) region of the hepatitis B surface antigen (HBsAg): a pre-S(1)-specific $\mathrm{T}$ cell response can bypass nonresponsiveness to the pre-S(2) and S regions of HBsAg. J. Immunol. 137:315-322.

27. Itho, Y., E. Takai, H. Ohnuma, K. Kitajima, F. Tsuda, A. Machida, S. Mishiro, T. Nakamura, Y. Miyakawa, and M. Mayumi. 1986. A synthetic pep tide vaccine involving the product of the pre-S(2) region of hepatitis B virus DNA protective efficacy in chimpanzees. Proc. Natl. Acad. Sci. USA 83.9174-9178.

28. Neurath, A. R., S. B. H. Kent, N. Strick, D. Stark, and P. Sproul. 1985 Genetic restriction of immune responsiveness to synthetic peptides corresponding to sequences in the pre-S region of the hepatitis B virus (HBV) envelope gene. J. Med. Vir. 17:119-125.

29. Milich, D. R., and A. McLachlan. 1986. The nucleocapsid of hepatitis B virus is both a T-cell-independent and a T-cell-dependent antigen. Science (Wash. DC). 234:1398-1401.

30. Murray, K., S. A. Bruce, A. Hinnen, P. Wingfield, P. Van Eerd, A. de Reus, and H. Schellekens. 1984. Hepatitis B virus antigens made in microbia cells immunize against viral infection. EMBO (Eur. Mol. Biol. Organ.) J. 3:645650.

31. Iwarson, S., E. Tabor, H. C. Thomas, P. Snoy, and R. J. Gerety. 1985. Protection against hepatitis $B$ virus infection by immunization with hepatitis B c antigen. Gastroenterology. 88:763-767.

32. Murray, K., S. A. Bruce, P. Wingfield, P. Van Eerd, A. de Reus, and H. Schellekens. 1987. Protective immunisation against hepatitis B with an internal antigen of the virus. J. Med. Virol. 23:101-107.

33. Roos, S., K. Fuchs, and M. Roggendorf, 1989. Protection of woodchucks from infection with woodchuck hepatitis virus by immunization with recombinant core protein. J. Gen. Virol. 70:2087-2095.

34. Clarke, B. E., S. E. Newton, A. R. Carroll, M. J. Francis, G. Appleyard, A. D. Syred, P. E. Highfield, D. J. Rowlands, and F. Brown. 1987. Improved immunogenicity of a peptide epitope after fusion to hepatitis B core protein. Nature (Lond.). 330:381-384.

35. Stahl, S. J., and K. Murray. 1989. Immunogenicity of peptide fusions to hepatitis B virus core antigen. Proc. Natl. Acad. Sci. USA. 86:6283-6287.

36. Milich, D. R., A. McLachlan, A. Moriarty, and G. B. Thornton. 1987 Immune response to hepatitis $B$ virus core antigen (HBcAg): localization of $\mathrm{T}$ cell recognition sites within $\mathrm{HBcAg} / \mathrm{HBeAg}$. J. Immunol. 139:1223-1231.

37. Buus, S., A. Sette, S. Colon, C. Miles, and H. M. Grey. 1987. The relation between major histocompatibility complex (MHC) restriction and the capacity of Ia to bind immunogenic peptides. Science (Wash. DC). 235:1353-1358.

38. Sinigaglia, F., M. Guttinger, J. Kilgus, D. M. Doran, H. Matile, H. Etlinger, A. Trzeciak, D. Gillessen, J. R. L. Pink. 1988. A malaria T-cell epitope recognized in association with most mouse and human MHC class II molecules. Nature (Lond.). 336:778-780.

39. Panina, P., A. Tan, A. Termijtelen, S. Demotz, G. Corradin, and A Lanzavecchia. 1989. Universally immunogenic T cell epitopes: promiscuous binding to human class II and promiscuous recognition by T cells. Eur. J. Immunol. 19:2237-2242.

40. Tiollais, P., C. Pourcel, and A. Dejean. 1985. The hepatitis B virus. Nature (Lond.). 317:489-495.

41. Uy, A., V. Bruss, W. M. Gerlich, H. G. Kochel, and R. Thomssen. 1986 Precore sequence of hepatitis $B$ virus inducing $e$ antigen and membrane association of the viral core protein. Virology. 155:89-96.

42. Roossink, M. J., S. Jameel, S. H. Loukin, and A. Siddiqui. 1986. Expression of hepatitis B viral core region in mammalian cells. Mol. Cell. Biol. 6:13931400 .

43. McLachlan, A., D. R. Milich, A. K. Raney, M. G. Riggs, J. L. Hughes, J. Sorge, and F. V. Chisari. 1987. Expression of hepatitis B virus surface and core antigens: influences of pre-S and precore sequences. J. Virol. 61:683-692.

44. Standring, D. N., J.-H. Ou, F. R. Masiarz, and W. J. Rutter. 1988. A signal peptide encoded within the precore region of hepatitis $B$ virus directs the secretion of a heterogeneous population of e antigens in Xenopus oocytes. Proc. Natl. Acad. Sci. USA. 85:8405-8409. 